\title{
Pemetaan Kompleksitas Habitat Dasar Perairan Menggunakan Data Batimetri di Perairan Pulau Kemujan Karimunjawa
}

\author{
Arip Rahman ${ }^{*}$, Vincentius P. Siregar2, James P. Panjaitan² \\ 'Balai Riset Pemulihan Sumber Daya Ikan, Kementerian Kelautan dan Perikanan Republik Indonesia \\ J. Cilalawi No. 1 Jatiluhur Purwakarta Jawa Barat 41152 Indonesia \\ 2Departemen Ilmu dan Teknologi Kelautan, Fakultas Perikanan dan Ilmu Kelautan, \\ Institut Pertanian Bogor \\ Jl. Agatis, Babakan, Kec. Dramaga, Kota Bogor, Jawa Barat 16126 Indonesia \\ Email : alphagrt79@gmail.com
}

\begin{abstract}
Mapping of Benthic Habitat Complexity Using Bathymetry Data In Kemujan Island Karimunjawa

The complexity of the substrate of the bottom waters describes the diversity of the bottom structure of the waters. The structure of the complexity of bottom waters can be measured by the rugosity. Manual method for measuring rugosity can be used chain method. Besides that rugosity can be calculated using bathymetry data using Surface Area from Elevation Grid Extension tools that integrated in ArcGIS which produces Arc-chord ratio (ACR) rugosity. Based on this method, a flat area has rugosity close to 1, while an area with high elevated will show rugosity value higher then 1 $(>1)$. Measurement of the complexity of the bottom waters is carried out to see the condition of benthic habitat in the shallow waters of Kemujan Island, Karimunjawa Islands. Based on the rugosity index, conditions of bottom waters of the Kemujan Island are quite complex (ACR rugosity index, 22.044). The ACR rugosity index correlated quite well with the rugosity index of the field measurement $(r=0.76)$.
\end{abstract}

Keywords: Complexity, rugosity index, arc-chord ratio, Kemujan Island, Karimunjawa

\begin{abstract}
Abstrak
Kompleksitas dasar perairan menggambarkan keragaman struktur dasar perairan. Struktur kompleksitas suatu dasar perairan dapat diukur dengan tingkat kekasaran (rugosity) dasar perairan. Metode pengukuran rugosity secara manual dilakukan dengan menggunakan metode rantai (chain). Selain itu rugosity juga dapat dihitung dengan menggunakan data kedalaman dengan menggunakan Surface Area from Elevation Grid Extension yang terintegrasi pada ArcGIS yang menghasilkan Arc-chord ratio (ACR) rugosity. Berdasarkan metode ini daerah datar memiliki nilai rugosity mendekati 1, sedangkan area dengan relief tinggi akan menunjukkan nilai rugosity yang lebih tinggi (>1). Pengukuran kompleksitas dasar perairan dilakukan untuk melihat kondisi habitat dasar di perairan dangkal Pulau Kemujan Kepulauan Karimunjawa. Berdasarkan indeks rugosity, kondisi dasar perairan Pulau Kemujan memiliki kompleksitas yang cukup tinggi (indeks ACR rugosity 2-2.044). Hal tersebut menggambarkan kondisi dasar perairan di sekitar lokasi penelitian cukup beragam. Indeks rugosity ACR berkorelasi cukup baik dengan indeks rugosity hasil pengukuran lapangan $(\mathrm{r}=0.76)$.
\end{abstract}

Kata Kunci: Kompleksitas, indeks rugosity, arc-chord ratio, Pulau Kemujan, Karimunjawa

\section{PENDAHULUAN}

Perairan Pulau Kemujan termasuk dalam wilayah perairan Taman Nasional Perairan
(TNP) Karimunjawa yang pengelolaannya dilakukan dengan sistem zonasi (Departemen Kehutanan, 2004). Berdasarkan pengamatan lapangan, komposisi dasar perairan di sekitar 
Perairan Pulau Kemujan terdiri dari karang hidup, karang mati yang ditumbuhi alga, pecahan karang yang ditutupi alga, dan pasir yang sebagian ditutupi dengan alga.

Terumbu karang merupakan salah satu contoh untuk melihat pengaruh kompleksitas habitat terhadap keanekaragaman dan kelimpahan organisme yang berasosiasi (Kovalenko et. al., 2012). Struktur kompleksitas merupakan heterogenitas dan tingkat ketidakteraturan struktur elemen yang merupakan susunan kontur topografi suatu lokasi (Taniguchi et.al., 2003). Struktur kompleksitas suatu dasar perairan dapat diukur dengan tingkat kekasaran (rugosity) dasar perairan tersebut (Knudby \& LeDrew, 2007). Struktur kompleksitas dasar perairan yang tinggi dapat digunakan untuk memperhitungkan kelimpahan spesies yang tinggi (Friedlander \& Parrish, 1998; Gratwicke \& Speight, 2005).

Analisis rugosity menghasilkan peta deskriptif yang membantu mengidentifikasi daerah dengan potensi keanekaragaman yang tinggi. Daerah dengan rugosity yang beragam merupakan prediktor penting dari lokasi habitat dan kepadatan suatu spesies (Young et.al., 2015). Secara ekologi, pentingnya struktur kompleksitas dasar perairan berhubungan dengan tempat berlindung organisme laut (Almany, 2004), relung fisik (Willis et.al., 2005), yang mendukung tingginya biodiversitas (Gratwicke \& Speight, 2005; Tews et al., 2004) dan meningkatkan carrying capacity dari suatu habitat (Kostylev et.al., 2005).

Pengukuran rugositas secara manual dilakukan dengan membandingkan panjang transek yang mengikuti kontur permukaan substrat dasar dengan panjang transek garis lurus dari titik awal sampai titik akhir pengukuran (Risk, 2012). Selain menggunakan metode manual, rugosity juga dapat dihitung dengan menggunakan data kedalaman dengan menggunakan add-in ArcGIS 10.5, Surface Area from Elevation Grid Extension (Jenness, 2013). Rugosity yang dihitung dengan menggunakan teknik ini berkorelasi tinggi dengan kemiringan (slope).

Pemetaan habitat dasar perairan merupakan suatu langkah awal kedepan kita memahami lingkungan laut, dan umumnya diperoleh dari gradient batimetri, yang mempengaruhi distribusi dan kelimpahan spesies (Brock et.al., 2004). Penelitian yang dilakukan bertujuan untuk memetakan kompleksitas dasar perairan di sekitar Pulau Kemujan dengan menggunakan data batimetri. Hasil penelitian diharapkan dapat menggambarkan kondisi habitat dasar perairan dangkal di sekitar perairan Pulau Kemujan.

\section{MATERI DAN METODE}

Pemetaan kompleksitas dasar perairan dangkal dilakukan di sekitar perairan Pulau Kemujan, Taman Nasional Perairan Karimunjawa, Jawa Tengah (5040' LS - 5057' LS dan 11004'BT - 110040' BT) (Gambar 1).

Data kedalaman diperoleh dari hasil pemeruman dengan menggunakan echosounder single beam GPS MAP 527xs. Data kedalaman hasil pemeruman dikoreksi terhadap rata-rata muka air laut rendah terendah (LLWL, Lowest Low Water Level). Sementara data citra satelit yang digunakan pada penelitian ini adalah citra satelit multispektral Sentinel-2A kanal sinar tampak (Band 2: biru, Band 3: hijau, Band 4: merah, dengan resolusi spasial $10 \mathrm{~m}$ ). Data batimetri di lokasi penelitian diestimasi dengan menggunakan data kedalaman hasil pemeruman dan data citra satelit Sentinel-2A yang telah terkoreksi dengan menggunakan model algoritma Support Vector Machine (SVM) (Rahman, Siregar, \& Panjaitan, 2020). Hasil perhitungan akurasi data batimetri dengan menggunakan model algoritma SVM diperoleh nilai $\mathrm{R}^{2}=0.57$ dan $\mathrm{RMSE}=0.73 \mathrm{~m}$.

Proses analisis rugosity yang dilakukan pertama membuat peta daerah kontur (contoured area) lokasi penelitian yang akan di ukur rugositinya. Selanjutnya menurun peta kemiringan (slope) dari contoured area yang dibuat sebelumnya. Langkah selanjutnya mengkonversi peta kemiringan (slope) menjadi planar area dengan mengikuti perhitungan rumus cosine (cos) dengan persamaan (Jenness, 2013):

$$
\text { planar area }=\frac{\text { horizontal area }}{\cos \theta}
$$


Horizontal area merupakan raster cell area, sedangkan $\theta$ merupakan perkalian antara slope raster hasil turunan dari batimetri dengan nilai 0.01745 yang merupakan hasil dari pi/180.

Perhitungan Arc-chord ratio (ACR) rugosity dengan persamaan (Jenness, 2013):

$$
\text { rugosity }=\frac{\text { contoured area }}{\text { planar area }}
$$

Berdasarkan metode ini area datar memiliki nilai rugosity mendekati 1, sedangkan area dengan relief tinggi akan menunjukkan nilai rugosity yang lebih tinggi $(>1)$.

\section{Pengukuran rugosity secara manual}

Rugosity secara manual/tradisional dievaluasi dengan cara pengukuran lapangan (insitu) (Gambar 2).

\section{HASIL DAN PEMBAHASAN}

Data kedalaman hasil estimasi model algoritma SVR yang digunakan pada penelitian ini berkisar antara $-0.5--6.78 \mathrm{~m}$ dengan kedalaman rata-rata $-2.4 \mathrm{~m}$. Hal tersebut menggambarkan bahwa perairan disekitar Pulau Kemujan termasuk perairan yang dangkal. Peta batimetri hasil estimasi model algoritma SVR disajikan pada Gambar 3.

Peta batimetri dalam format raster yang dihasilkan menjadi masukan (input) dalam perhitungan Arc-chord Ratio (ACR) rugosity yang digunakan untuk menganalisis kompleksitas dasar perairan di sekitar perairan Pulau Kemujan. Hasil pengolahan batimetri secara tiga dimensi (3D) disekitar lokasi penelitian memperlihatkan adanya cekungan yang dibatasi oleh permukaan yang lebih tinggi disekitarnya. Hasil survey lapangan menunjukan bahwa daerah cekungan tersebut cukup terlindung, sehingga nelayan setempat memanfaatkan lokasi cekungan tersebut untuk budidaya rumput laut dan lokasi penangkapan ikan dengan menggunakan pancing dan jaring.

\section{Kemiringan (slope) merupakan turunan pertama dari data batimetri yang menggambarkan derajat kemiringan lereng dasar perairan (Gambar 4). Kemiringan dasar perairan dianggap sebagai faktor penting dalam menentukan habitat bentik dan suatu koloni di laut dalam berbagai skala (Wilson et al., 2007). Daerah yang datar memperlihatkan permukaan dasar laut yang berbeda dan mendukung komunitas yang berbeda dengan daerah yang memiliki kemiringan (Lundblad et al., 2006).}

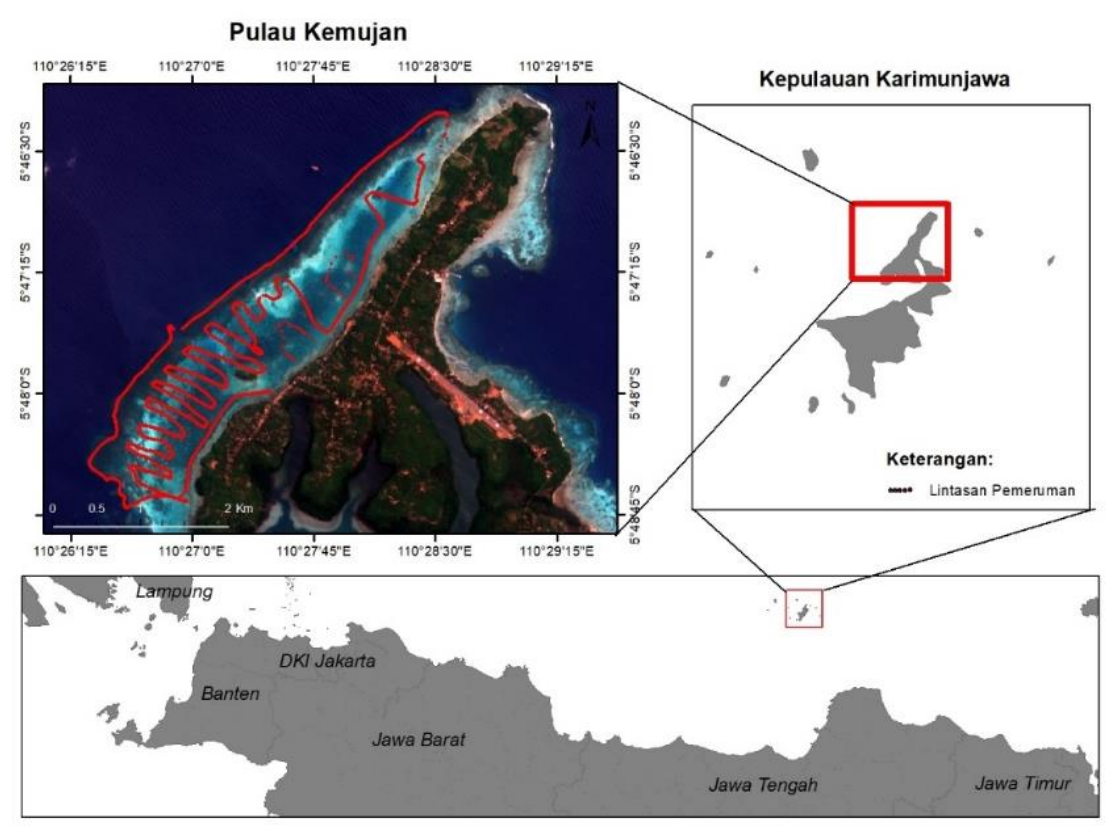

Gambar 1. Peta lokasi penelitian dan lintasan pemeruman di lokasi penelitian 
Kemiringan juga dapat membantu penguatan aliran arus (Mohn \& Beckmann, 2002), yang berpengaruh terhadap ketersediaan makanan pada bentik fauna. Berkaitan dengan antropogenik, kemiringan menjadi faktor pembatas dalam penggunaan alat tangkap tertentu (Grehan et al., 2005).

Berdasarkan hasil pengamatan dengan melakukan snorkeling dan penyelaman, lokasi dengan kemiringan $>30$ merupakan celah antara terumbu karang yang cukup dalam dan biasanya dijadikan jalur masuk kapal ke pinggir pantai oleh nelayan setempat. Sedangkan area dengan kemiringan $<10$ merupakan hamparan pasir yang bercampur dengan pecahan karang (rubber).

\section{Hasil perhitungan rugosity $A C R$}

Nilai rugosity dalam penelitian ini diperoleh dengan menggunakan metode arc-chord ratio (ACR) Surface Area to Planar Area dengan membagi contoured area dengan planar area dengan menggunakan raster calculator (Gambar 5). Area kontur (contoured area) diperoleh dari hasil analisis data kedalaman (batimetri) dengan menggunakan perangkat lunak Digital Elevation Model (DEM) Surface Tools, sedangkan planar area merupakan peta konversi dari peta kemiringan (slope) (Jenness, 2013). Nilai rugosity yang diperoleh berdasarkan hasil analisis menggunakan luas area sel $50 \mathrm{~m}^{2}$. Penentuan luas area sel dilakukan dengan melakukan percobaan (trial and error) pada saat penentuan planar area sampai diperoleh gambaran yang dianggap mewakili daerah penelitian.
Kisaran nilai rugosity yang dihasilkan berdasarkan surface area to planar area pada luasan $50 \mathrm{~m}^{2}$ dilokasi penelitian berkisar antara 2-2.044. Berdasarkan metode ini, area datar memiliki nilai rugosity mendekati 1 , sedangkan area dengan relief tinggi menunjukkan nilai rugosity yang lebih tinggi $(>1)$. Beberapa peneliti telah menghubungkan antara kompleksitas suatu area dengan distribusi fauna (Beck, 2000; Kostylev et al., 2005), dan pada skala tertentu dapat menjadi parameter kunci dalam membedakan kesesuaian habitat untuk jenis fauna tertentu.

\section{Perbandingan rugosity ACR dengan hasil pengukuran manual.}

Pengukuran rugosity secara insitu dilakukan dengan melakukan penyelaman dan mengukur tingkat kekasaran dasar perairan dengan menggunakan metode rantai (chain) (Hill \& Wilkinson, 2004). Lokasi geografis pengukuran dicatat dari Global Positioning Sistem (GPS) dengan akurasi $3 \mathrm{~m}$. Hasil pengukuran rugosity insitu dihubungkan dengan nilai $A C R$ rugosity disajikan pada Tabel 1.

Perbandingan antara rugosity $A C R$ (area) dan pengukuran manual (panjang) untuk melihat hubungan antara kedua nilai indeks rugosity di lokasi penelitian. Hasil korelasi antara nilai indeks rugositas secara insitu dan model ACR rugosity cukup baik dengan nilai $r=0.76$. (Gambar 6). Hal tersebut mengindikasikan bahwa perhitungan rugosity menggunakan data satelit dengan metode ACR rugosity cukup menggambarkan kondisi kompleksitas di lokasi penelitian.

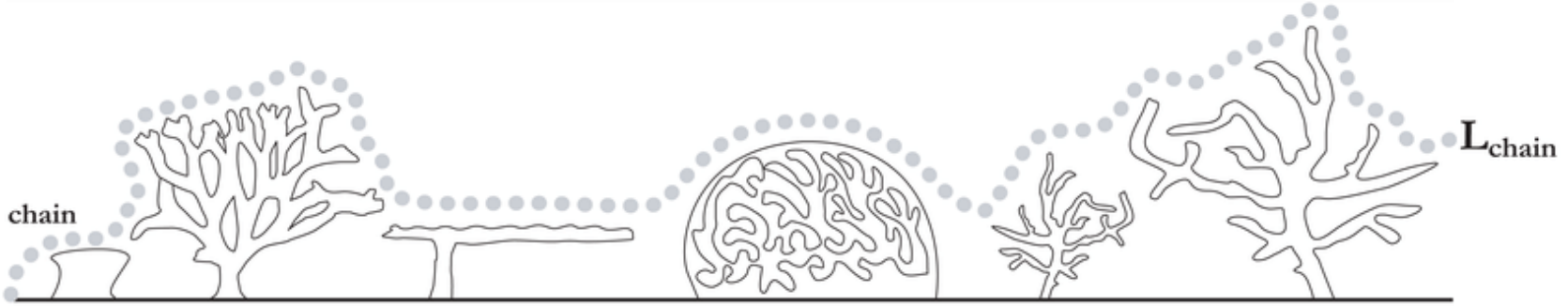

$$
\text { Rugosity }=\frac{L_{\text {chain }}}{D_{\text {chain }}}
$$

Gambar 2. Pengukuran kekasaran dasar perairan (rugosity) secara insitu (modifikasi dari Hill \& Wilkinson, 2004) 

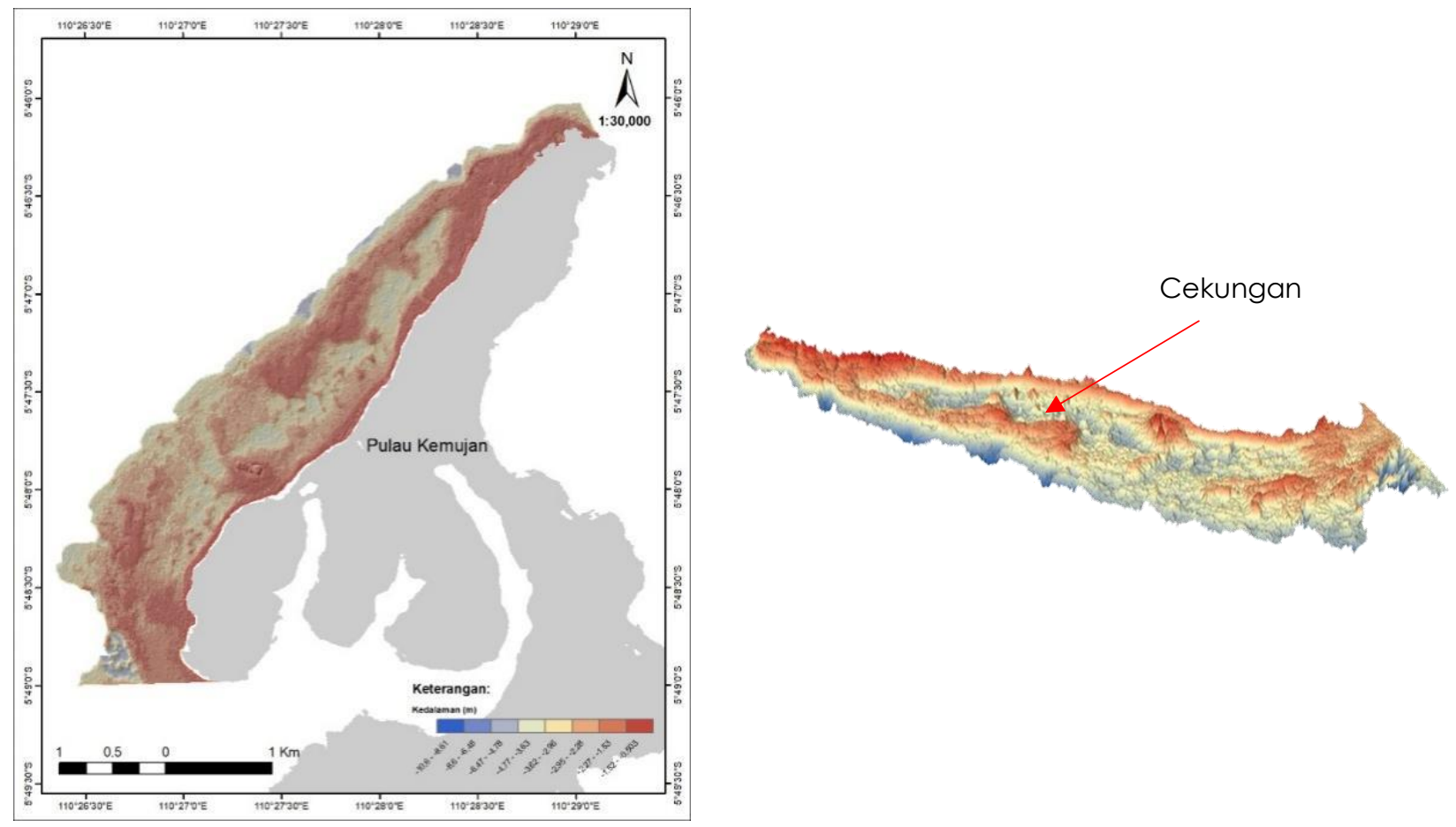

Gambar 3. Peta batimetri hasil estimasi model algoritma SVR (Rahman et al., 2020)

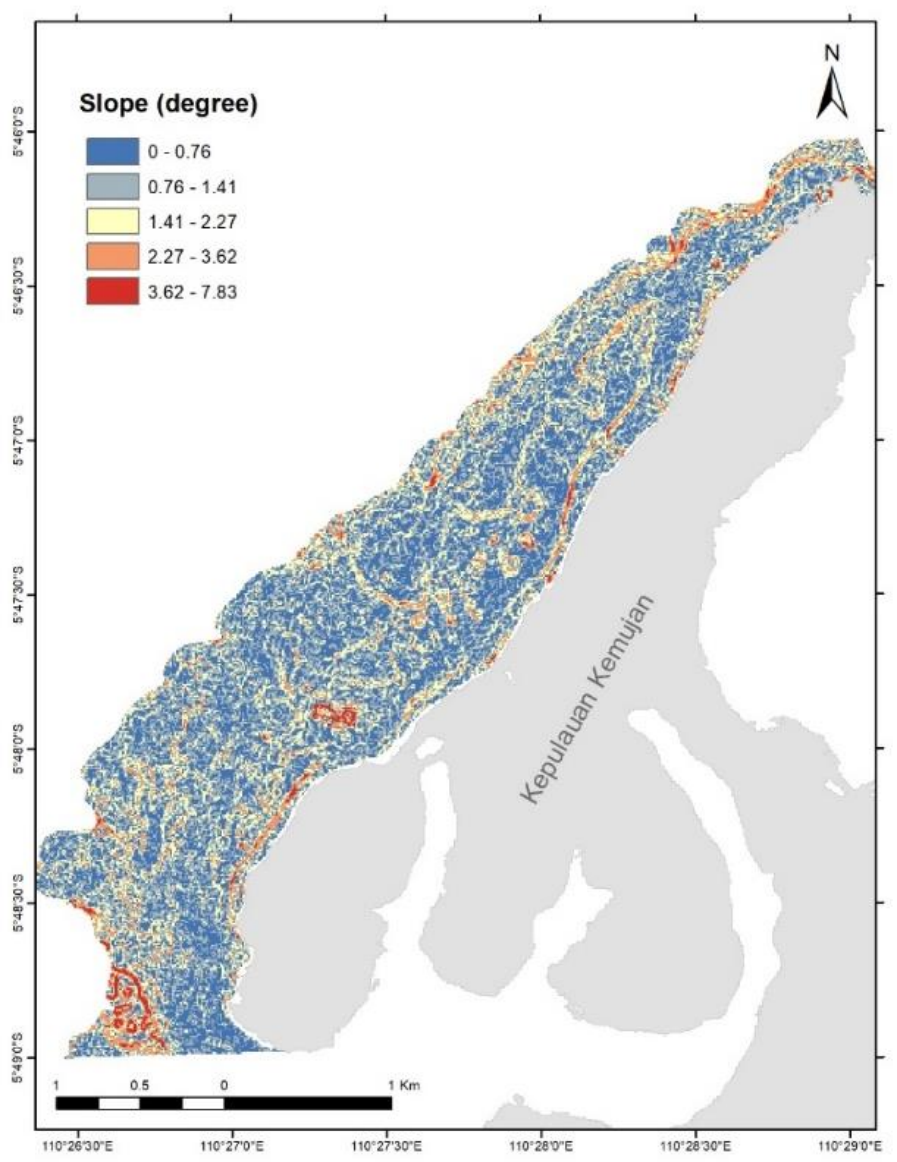

Gambar 4. Gambaran kemiringan (slope) di lokasi penelitian perairan Pulau Kemujan 

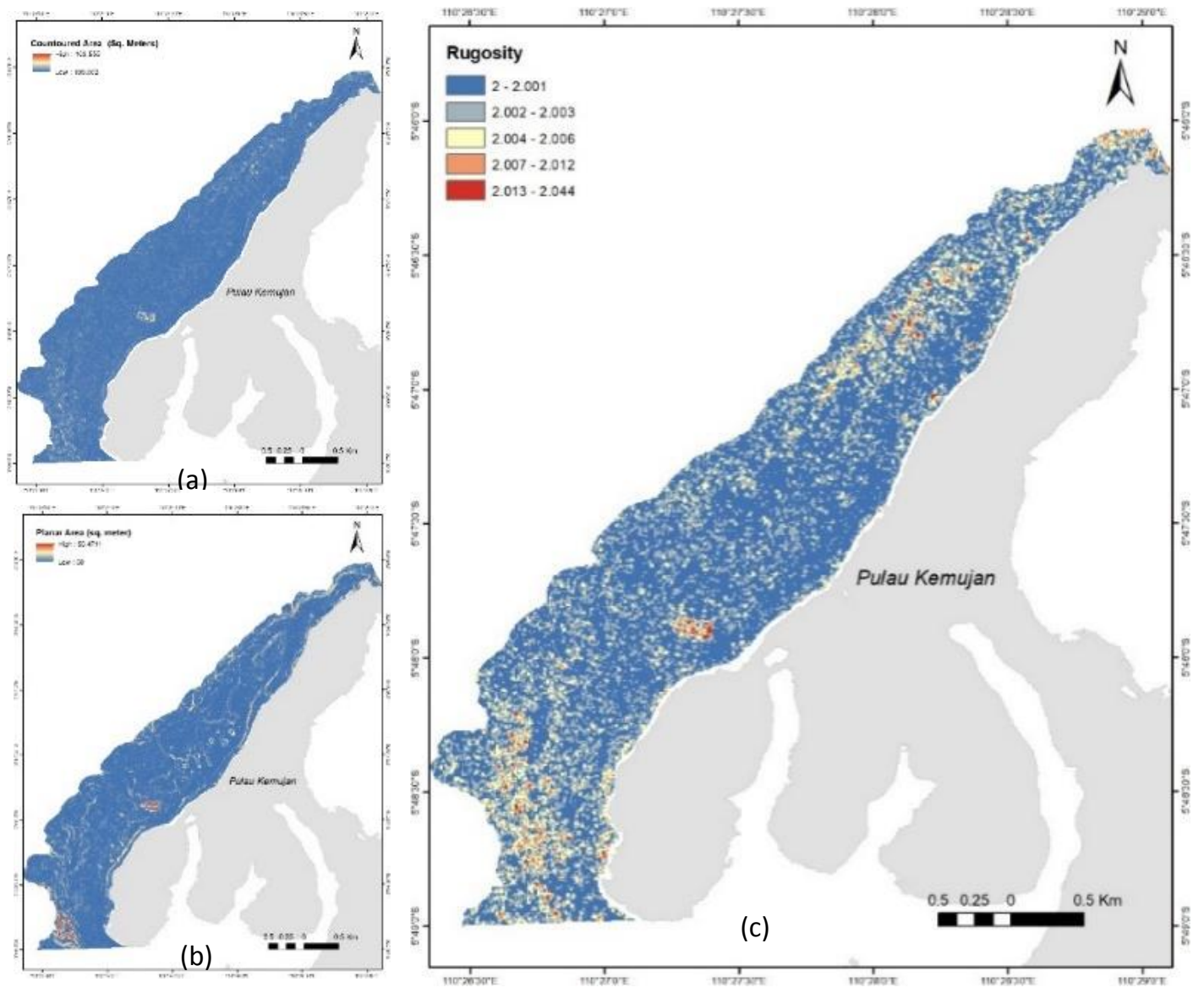

Gambar 5. (a) Peta kontur (contoured area), (b) peta planar area, (c) Peta ACR rugosity dasar perairan berdasarkan.

Tabel 1. Indeks Rugosity hasil pengukuran insitu dan model ACR rugosity

\begin{tabular}{lrrrr}
\hline Posisi & $\mathrm{L}(\mathrm{m})$ & $\mathrm{D}(\mathrm{m})$ & $\mathrm{R}$ (insitu) & $\mathrm{R}(\mathrm{ACR})$ \\
\hline transek 1_trip 1 & 5 & 3.8 & 1.32 & 2.0011 \\
transek 2_trip 1 & 5 & 4.7 & 1.06 & 2.0002 \\
transek 3_trip 1 & 5 & 4.4 & 1.14 & 2.0005 \\
transek 4_trip 1 & 5 & 2.57 & 1.95 & 2.0068 \\
transek 5_trip 1 & 5 & 2.9 & 1.72 & 2.0027 \\
transek 6_trip 1 & 5 & 2.75 & 1.82 & 2.0020 \\
Transek 1_trip2 & 5 & 4.8 & 1.04 & 2.0009 \\
Transek 2_trip2 & 5 & 4.3 & 1.16 & 2.0009 \\
Transek 3_trip2 & 5 & 3.6 & 1.39 & 2.0023 \\
Transek 4_trip2 & 5 & 4 & 1.25 & 2.0006 \\
Transek 5_trip2 & 5 & 4.7 & 1.06 & 2.0017 \\
Transek 6_trip2 & 5 & 3 & 1.67 & 2.0034 \\
\hline
\end{tabular}

Keterangan: L panjang rantai (m), D jarak horizontal rantai yang mengikuti kontur dasar perairan (m) R nilai rugosity (L/d), ACR (Arc-chord Ratio) 

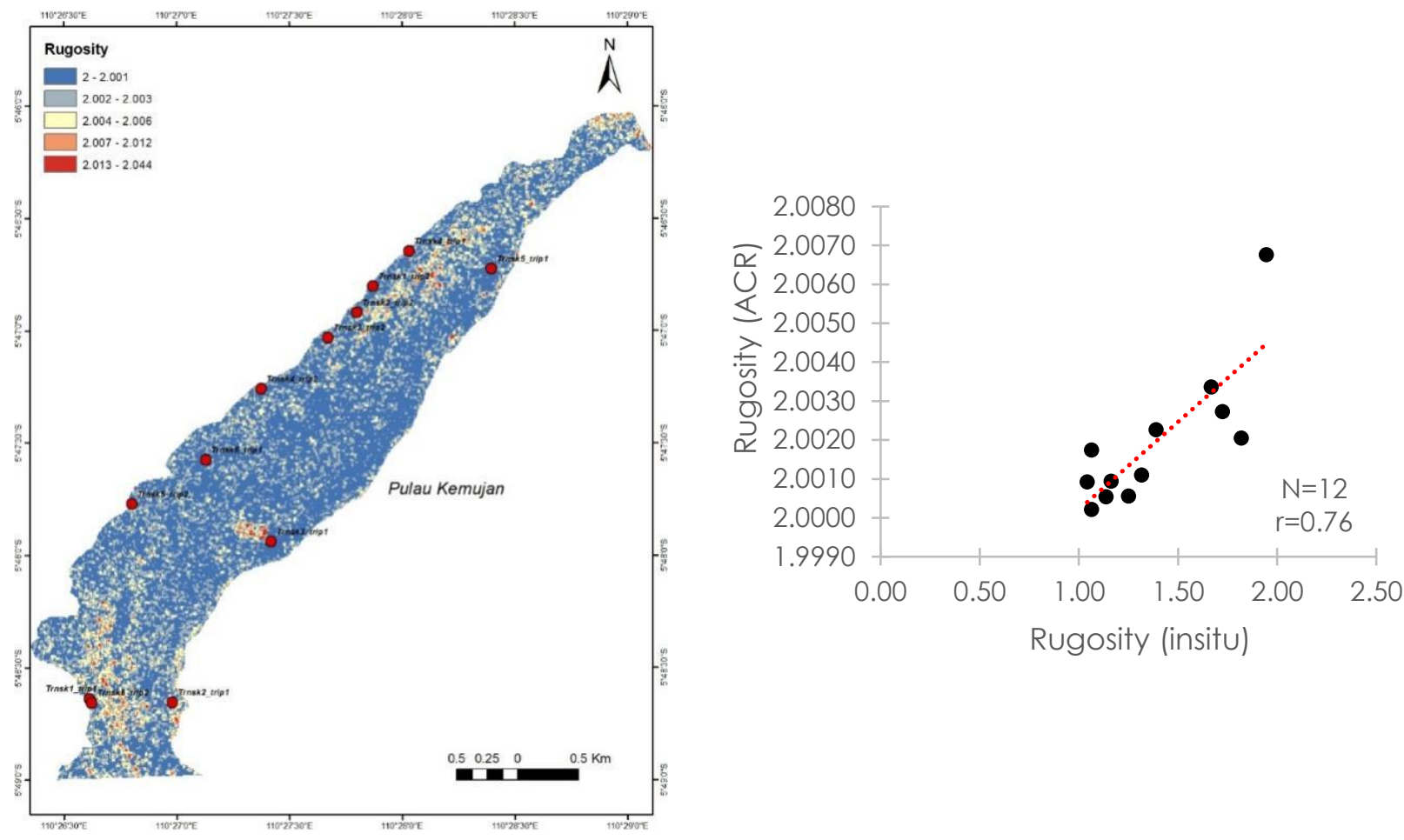

Gambar 6. Hubungan antara nilai rugosity insitu dan ACR rugosity (Lokasi pengukuran rugosity secara insitu (O))

\section{KESIMPULAN}

Data batimetri dapat digunakan untuk melihat kompleksitas dasar perairan dangkal. Berdasarkan indeks rugosity, kondisi dasar perairan Pulau Kemujan memiliki kompleksitas yang cukup tinggi. Indeks rugosity ACR berkorelasi cukup baik dengan indeks rugosity hasil pengukuran lapangan (insitu) ( $r=0.76)$. Penelitian lanjutan diperlukan untuk melihat korelasi antara kompleksitas dasar perairan dengan biota yang ada di sekitarnya.

\section{DAFTAR PUSTAKA}

Almany, G.R. 2004. Differential effects of habitat complexity, predators and competitors on abundance of juvenile and adult coral reef fishes. Oecologia, 141(1):105-113. doi: 10.1007/s00442-004$1617-0$

Beck, M.W. 2000. Separating the elements of habitat structure: Independent effects of habitat complexity and structural components on rocky intertidal gastropods. Journal of Experimental Marine Biology and Ecology, 249(1):2949. doi: 10.1016/S0022-0981(00)00171-4

Brock, J.C., Wright, C.W., Clayton, T.D., \& Nayegandhi, A. 2004. LIDAR optical rugosity of coral reefs in Biscayne National Park, Florida. Coral Reefs, 23(1):48-59. doi: $10.1007 / \mathrm{s} 00338-003-0365-7$

Departemen_Kehutanan. 2004. Penataan Zonasi Taman Nasional Karimunjawa Kabupaten Jepara Propinsi Jawa Tengah.

Friedlander, A.M., \& Parrish, J.D. 1998. Habitat characteristics affecting fish assemblages on a Hawaiian coral reef, 224:1-30.

Gratwicke, B., \& Speight, M.R. 2005. The relationship between fish species richness, abundance and habitat complexity in a range of shallow tropical marine habitats. Journal of Fish Biology, 66(3):650-667. doi: $10.1111 /$ j.0022-1112.20 05.00629.x

Grehan, A.J., Unnithan, V., Olu, K., \& Opderbecke, J. 2005. Fishing impacts on Irish deep-water coral reefs: making the case for coral conservation. In 
Symposium on the Effects of Fishing Activities on Benthic Habitats: Linking Geology, Biology, Socioeconomics and Management, pp. 819-832

Hill, J., \& Wilkinson, C. 2004. Methods for ecological monitoring of coral reefs. Australian Institute of Marine Science, Townsville, January 2004: 117. doi: 10.1017/CBO9781107415324.004

Jenness, J. 2013. DEM surface tools for ArcGIS [Electronic manual]. Jenness Enterprises.

Knudby, A., \& LeDrew, E. 2007. Measuring structural complexity on coral reefs. In Proceedings of the American Academy of Underwater Sciences 26th Symposium, pp.181-188. doi: 10.1080/13556207.2006. 10784979

Kostylev, V.E., Erlandsson, J., Mak, Y.M., \& Williams, G.A. 2005. The relative importance of habitat complexity and surface area in assessing biodiversity: Fractal application on rocky shores. Ecological Complexity, 2(3):272-286. doi: 10.1016/j.ecocom.2005.04.002

Kovalenko, K.E., Thomaz, S.M., \& Warfe, D.M. 2012. Habitat complexity: Approaches and future directions. Hydrobiologia, 685(1):1-17. doi: 10.1007/s10750-011-0974-z

Lundblad, E.R., Wright, D.J., Miller, J., Larkin, E.M., Rinehart, R., Naar, D.F., Donahue, B.T., Anderson, S.M. \& Battista, T., 2006. A benthic terrain classification scheme for American Samoa. Marine Geodesy, 29(2):89-111. doi: 10.1080/014904106007 38021

Mohn, C., \& Beckmann, A. 2002. Numerical studies on flow amplification at an isolated shelfbreak bank, with application to Porcupine Bank. Continental Shelf Research, 22(9):13251338. doi: 10.1016/S0278-4343(02)00004-3
Rahman, A., Siregar, V.P., \& Panjaitan, J. 2020. Estimasi kedalaman perairan dangkal menggunakan data citra satelit multispektral Sentinel-2A. Jurnal Segara, 16:151-162. doi: 10.15578/segara.v16i3.8562

Risk, M.J. 2012. Fish Diversity on a Coral Reef in the Virgin Islands. Atoll Research Bulletin, 153:1-4. doi: 10.5479/si.00775630.153.1

Taniguchi, H., Nakano, S., \& Tokeshi, M. 2003. Influences of habitat complexity on the diversity and abundance of epiphytic invertebrates on plants. Freshwater Biology, 48(4):718-728. doi: 10.1046/j.136 5-2427.2003.01047.x

Tews, J., Brose, U., Grimm, V., Tielbörger, K., Wichmann, M.C., Schwager, M., \& Jeltsch, F. 2004. Animal species diversity driven by habitat heterogeneity/diversity: The importance of keystone structures. Journal of Biogeography, 31(1):79-92. doi: 10.1046/j.0305-0270.2003.00994.x

Willis, S.C., Winemiller, K.O., \& LopezFernandez, H. 2005. Habitat structural complexity and morphological diversity of fish assemblages in a Neotropical floodplain river. Oecologia, 142(2):284295. doi: 10.1007/s00442-004-1723-z

Wilson, M.F.J., O'Connell, B., Brown, C., Guinan, J.C., \& Grehan, A.J. 2007. Multiscale terrain analysis of multibeam bathymetry data for habitat mapping on the continental slope. Marine Geodesy 30(1-2):3-35.. doi: 10.1080/014904107012 95962

Young, M., lerodiaconou, D., \& Womersley, T. 2015. Forests of the sea: Predictive habitat modelling to assess the abundance of canopy forming kelp forests on temperate reefs. Remote Sensing of Environment, 170:178-187. doi: 10.1016/j. rse.2015.09.020 